\title{
Criminaliteit onder Marokkaanse jongemannen in Nederland: speelt regionale herkomst een rol?
}

\author{
Frank Bovenkerk \& Tineke Fokkema
}

In de sociologie van migratie en criminaliteit worden hoge cijfers van geregistreerde misdaad bij jongemannen van de tweede generatie immigranten gewoonlijk toegeschreven aan sociale desorganisatie van de betreffende etnische groep en de zwakke sociaaleconomische positie die deze in het nieuwe land inneemt. Daar staat het vermoeden tegenover dat de oorzaken van de criminaliteit ook reeds in het land of de streek van herkomst moeten worden gezocht. Dit wordt onderkend in de importtheorie. Er zijn echter meestal geen empirische gegevens voorhanden om dit vermoeden te toetsen. In het geval van de Marokkaanse criminaliteit in Nederland bestaan zulke aanwijzingen wel. Er is etnografisch en pedagogisch onderzoek verricht bij kleine groepen van delinquente jongens waarbij een verklaring wordt gezocht in de regionale achtergrond (vooral van het platteland of het Rifgebergte) van de immigranten in Marokko. In dit artikel wordt nagegaan of deze aanwijzingen standhouden bij kwantitatief onderzoek naar de groep als geheel. De registratie van politiecontacten (ooit verdacht van een misdrijf) uit het HKS op persoonsniveau wordt in verband gebracht met persoonsgegevens uit het Stelsel van Sociaal-statistische Bestanden (SSB) van het Centraal Bureau voor de Statistiek, inclusief herkomstregio (van ouders). Met behulp van logistische regressieanalyse wordt aangetoond dat sociaaleconomische status in Nederland een zeer belangrijke voorspeller is voor crimineel gedrag, terwijl de invloed van regionale afkomst, direct of indirect via sociaaleconomische positie in Nederland, verwaarloosbaar is. Er bestaat op grond van deze studie geen reden om de gangbare theorie over het verband tussen migratie en misdaad te herzien.

\section{Inleiding}

Het is nu vijftig jaar geleden dat de eerste Marokkaanse mannen als gastarbeiders naar Nederland kwamen. Ongeveer de helft van hen heeft, vooral na de oliecrisis van 1973 en na de economische recessie van de beginjaren tachtig, zijn gezin over laten komen of gesticht (De Beer e.a., 1991) en daaruit heeft zich de Marokkaanse immigrantengroep gevormd die thans (1 januari 2014) volgens opgave van het Centraal Bureau voor de Statistiek (CBS) 374.694 mensen omvat. Er zijn nu een eerste, een anderhalve (voor een deel opgegroeid in Marokko en daarna in Nederland) en een tweede generatie van Marokkaanse Nederlanders te onderscheiden. De oorspronkelijke immigranten zijn voor ruim twee derde afkomstig uit (a) het gebied van het Rifgebergte langs de noordkust, (b) het zuiden in de streek rond Agadir (Souss), Ouarzazate en (c) de steden Tanger, Casablanca, Fès, Meknès, Marrakech en Rabat. In Nederland hebben de Marokkanen zich vooral gevestigd in de vier grootste steden van de Randstad, in overige grote steden, zoals Gouda, 
Almere, Leiden, Haarlem, Eindhoven en Tilburg, en in enkele middelgrote steden, zoals Veenendaal, Ede en Culemborg (Fokkema e.a., 2009).

In deze bevolkingsgroep heeft zich vanaf 1990 een hardnekkig probleem van criminaliteit onder jonge mannen ontwikkeld. Tegen meer dan de helft van de anderhalve en tweede generatie Marokkaanse jongens is thans vóór het bereiken van het 23ste levensjaar proces-verbaal opgemaakt ter zake van een of meer misdrijven of delicten (Blokland e.a., 2010). Het Jaarrapport integratie 2011 noemt zelfs een percentage van 65 (Van Noije \& Kessels, 2012, 207). Deze hoge criminaliteit onder de jongeren is opmerkelijk omdat onder de eerste generatie immigranten sprake is geweest van een lagere criminaliteit dan gemiddeld. Het gaat daarbij niet alleen om kleine criminaliteit, zoals het veroorzaken van buurtoverlast, vandalisme of het lastigvallen van vrouwen en meisjes (Bahara, 2012), maar ook om 'high-impact' delicten, zoals straatroof, inbraak en overvallen. Marokkaanse criminaliteit komt verder voor bij de handel in drugs (Van Wijk \& Bremmers, 2011), pooierij of het optreden als 'loverboys' (Bovenkerk e.a., 2009) en huiselijk geweld (Yarden, 2008). Vooral de gewelddadige overvallen trekken op dit ogenblik sterk de aandacht (Vugts, 2014) en dat geldt nog meer voor de criminele afrekeningen in wat de mocro-oorlogen worden genoemd (Laumans \& Schrijver, 2014).

Aanvankelijk leek het erop dat deze hoge uitslagen te verklaren zouden zijn uit de oververtegenwoordiging van Marokkaanse jongens in de lagere sociale milieus. Maar reeds in 1990 is door Junger op grond van zelfgerapporteerde gegevens vastgesteld dat de Marokkaanse criminaliteitscijfers voor deze leeftijdsgroep significant hoger zijn dan gemiddeld in de laagste sociaaleconomische klasse en dan die van andere minderheidsgroepen (met uitzondering van die van Antillianen). Onderzoekers van het Sociaal en Cultureel Planbureau en het CBS hebben voor het jaar 2009 op grond van het aantal verdachten van misdrijven in het Herkenningsdienstsysteem (HKS) van de politie uitgerekend in hoeverre algemeen geldende risicofactoren (geslacht, leeftijd, genoten opleiding, inkomen, stedelijkheid) de mate van oververtegenwoordiging van verschillende groepen van nietwesterse jongeren verklaren. Dit blijkt voor de groep Marokkanen het minst (Van Noije \& Kessels, 2012, 214-215).

Deze hoge uitslag van de geregistreerde criminaliteit zou het gevolg kunnen zijn van selectiviteit bij de opsporing en berechting speciaal van jongens met een Marokkaanse achtergrond. Maar ook deze veronderstelling lijkt niet tegen toetsing aan de feiten bestand. Weliswaar werkt het strafrechtelijk apparaat behalve naar klasse, geslacht en leeftijd wellicht ook naar etnische afkomst selectief (zie Amnesty International (2013) over het zogenaamd etnisch profileren door de politie), maar het viel ten tijde van de 'ontdekking' van het probleem van criminaliteit onder de tweede generatie van immigranten niet in te zien dat dit speciaal ten nadele van Marokkanen uit zou vallen (Junger, 1991, 325). Wel is denkbaar dat de verhouding tussen de politie en Marokkanen intussen zodanig is verslechterd dat selectiviteit in het strafrechtelijk systeem een deel van het probleem is geworden (Driessen e.a., 2014). De relatief hoge criminaliteit van Marokkaanse jongemannen wordt nu al twintig jaar, ook in de politiek, als een bijzonder probleem beschouwd. 
Hoe kan dit vraagstuk wel worden verklaard? In de criminologie doet een veelheid aan theorieën de ronde om de relatief hoge criminaliteit van (de tweede generatie van) immigranten en etnische minderheden te verklaren (zie Bovenkerk, 2002; Junger-Tas, 2002; Van der Leun e.a., 2010). Bij de meeste empirische studies wordt gezocht binnen het land van vestiging op grond van theorieën van maatschappelijke integratie, relatieve deprivatie, sociale desorganisatie en sociale binding. Het gaat dan om algemeen werkzame sociale processen die bijzonder uitwerken op minderheden. Soms - zij het veel minder vaak - wordt ook teruggekeken naar het land of de streek waar de immigranten vandaan komen. Volgens Mears $(2001,10)$ is zo'n terugblik wel noodzakelijk bij de ontwikkeling van elke theorie over de 'immigrant-crime nexus'. Criminaliteit vloeit dan voort uit het lage ontwikkelingspeil of een bijzondere politieke en culturele traditie van het gebied waar de immigranten vandaan komen. Dit noemen we het importmodel. In de theorieën van cultuurconflict, culturele deviantie en culturele dissonantie vormt de cultuur van het land of de landstreek van herkomst een constituerend element. Criminaliteit ontstaat volgens dit gezichtspunt in de interactie tussen (elementen van) de cultuur in de landen van herkomst en vestiging.

In het geval van de Marokkaanse criminaliteit in Nederland wordt door criminologen en cultureel antropologen wel veelvuldig verwezen naar de achtergrond van de immigranten en hun cultuur. Dat geldt met name voor de meerderheid van immigranten die afkomstig zijn van het platteland of uit het economisch en sociaal achtergebleven Rifgebergte. De Rif-Marokkanen zijn volgens hen bovendien afkomstig uit een schaamtecultuur, ze komen uit een sociale omgeving waarin mensen elkaar wantrouwen en ze kennen een traditie van verzet tegen de overheid. Deze opvattingen worden breed gedeeld in Marokkaanse kring en de betreffende jongens zelf beroepen zich ter verklaring van hun optreden op de strijdbare reputatie van het volk van de Rif.

Wat zijn die verwijzingen waard? Ze berusten op etnografisch veldwerk onder groepen van overlastgevende Marokkaanse jongens in de grote steden van Nederland (Van Gemert, 1998; Werdmölder \& Meel, 1993), op pedagogisch onderzoek in Marokkaanse gezinnen en op psychologische studies van individuele delinquenten in Nederland (Brons e.a., 2008; Database wetenschappelijke onderzoeken \& deskundigen, $2012^{1}$ ). Zulke studies leveren kwalitatief interessante inzichten op, maar is het verantwoord om de resultaten te generaliseren voor alle Marokkanen in Nederland?

Wij verkeren in Nederland nochtans in de uitzonderlijke omstandigheid dat we goed geïnformeerd zijn over de plaats of streek in Marokko waar degenen die in Nederland met de politie in aanraking komen of hun ouders vandaan komen. We weten de geboorteplaats in Marokko van alle eerste en anderhalve generatie immigranten of, voor de tweede generatie, die van hun ouders. Deze plaatsen zijn gecodeerd naar de 61 onderscheiden provincies in Marokko en deze codes zijn op hun beurt gekoppeld aan de verdachtenregistraties uit het HKS van het Korps landelijke politiediensten (KLPD) op persoonsniveau. Door criminaliteitscijfers

1 Deze database is vervaardigd in opdracht van het Samenwerkingsverband aanpak MarokkaansNederlandse risicojongeren. 
per streek van herkomst te vergelijken is het mogelijk om een antwoord te formuleren op de hoofdvraag van dit onderzoek: moet de oorsprong van het Marokkaanse criminaliteitsprobleem in de eerste plaats worden gezocht in Marokko of ontstaat het in Nederland? Of specifieker gesteld: is de criminaliteit van Marokkaanse jongemannen inderdaad een kwestie van afkomst uit de Rif of van het platteland?

\section{Migratie en criminaliteit}

\subsection{Socialedesorganisatietheorie: van het platteland in Marokko naar de stad in Nederland}

De theorievorming over de samenhang tussen immigratie en criminaliteit laat men gewoonlijk beginnen aan het sociologisch departement van de Universiteit van Chicago in de jaren twintig van de vorige eeuw, waar de onderzoekers er de naam socialedesorganisatietheorie aan gaven. Hier werd door auteurs Shaw en McKay (1942) voor het eerst met cijfers aangetoond dat de criminaliteit onder de immigranten zelf niet hoger was dan gemiddeld, maar juist lager. Deze uitkomst vormde een belangrijk argument tegen de wens van sommige politici van die tijd, die erop aandrongen om de immigratie te stoppen omdat dit de veiligheid in Amerika zou bedreigen. Maar de cijfers die betrekking hadden op degenen die in Amerika waren geboren (de tweede generatie), waren wel hoger dan gemiddeld. De ouders waren nog gesocialiseerd in de homogene en stabiele sociale verbanden in het herkomstland, waar zij hadden geleerd om de wet te respecteren. Hun kinderen groeiden daarentegen op in de sociale en cultureel heterogene omgeving van de moderne stad, waar minder sociale controle op hen werd uitgeoefend. De ouderlijke generatie stelde zich tevreden met een mindere werkkring en een laag inkomen omdat zij deze vergeleken met de economische en politieke omstandigheden van het land van herkomst. De tweede generatie vergeleek zich op school en op straat echter met de 'Amerikanen' en stelde hogere materiële eisen, en dat leverde 'strain' op. Veel kinderen van deze generatie ervoeren bij hun aanpassingsproces tevens vervreemding, die het gevolg was van een gebrek aan sociale stabiliteit, normatieve consensus en sociale cohesie binnen hun bevolkingsgroep. Wanneer de tweede generatie ouder werd, verminderde de misdadigheid binnen dit cohort wel. Nu volgde het gebruikelijke verloop van de 'age-crime-curve': vanaf het moment dat gezinnen werden gesticht, trokken de meeste (jeugd)delinquenten zich uit de misdaad terug.

Sociale desorganisatie was in de ogen van de Chicago-sociologen een proces dat zich afspeelde in Amerika en dat primair werd veroorzaakt door ontwikkelingen binnen de geografie van de steden. De criminaliteit was hoog in buurten met veel werkloosheid tijdens economische recessies, waar arbeiders lage lonen verdienden, waar relatief veel gezinnen afhankelijk waren van enige vorm van bijstand of liefdadigheid, waar de woningen klein waren en dicht op elkaar stonden. In hun ogen was criminaliteit de uitkomst van sociaaleconomische achterstand en onafhankelijk van de vraag welke etnische groep er zich daar op dat ogenblik ook had gevestigd. Elke nieuwe immigrantengroep moest van onderop beginnen en zag 
zich gedwongen in de slechtste buurten te gaan wonen. De achterstand zou pas verminderen als de migranten verhuisden naar betere buurten.

De bevindingen uit Chicago over de delinquentie werden in Europa bevestigd door Ferracuti, die er in 1968 een overzichtswerk over schreef: de immigrantengeneratie zelf vertoonde weinig misdaad (het ging vaak om mannen alleen die werk hadden), maar de tweede generatie van sommige etnische groepen liet wel hoge criminaliteitscijfers zien. In 1996 heeft Yaeger deze algemene regel in een meta-analyse waarbij ook de ervaringen van Canada en Australië waren verdisconteerd, nog eens bevestigd: de criminaliteit van de eerste generatie immigranten is lager dan die van de autochtonen. Die van de tweede generatie is hoger dan gemiddeld in het land.

In deze desorganisatietheorie is de rol van de anderhalve generatie interessant. De jongeren die hiertoe behoren - de grens van 'anderhalf' wordt doorgaans gelegd bij een immigratieleeftijd van 12 jaar (Rumbaut, 1991) - zijn voor een deel opgevoed binnen de stabiele sociale omgeving in het land van herkomst en op grond daarvan zou men minder criminaliteit verwachten dan bij de tweede generatie, die in volle omvang heeft blootgestaan aan de ontregelende invloeden van het land van vestiging.

Het ligt voor de hand te veronderstellen dat het effect van sociale desorganisatie groter is naarmate de samenlevingen van herkomst en vestiging in sociaaleconomisch opzicht meer van elkaar verschillen. Immigranten die afkomstig zijn uit een kleinschalige gemeenschap van het arme platteland en die weinig opleiding hebben meegekregen, zullen meer moeite hebben met de overgang naar de anonieme stedelijke samenleving met al haar economische en educatieve uitdagingen dan mensen die in het land van afkomst wel stedelijke ervaring en onderwijs hebben opgedaan. Eisenstadt, die deze gedachtelijn volgde om de hoge misdaadcijfers onder de tweede generatie van Sefardische joden (Marokkanen!) in Israël te verklaren, zei het zo:

'The disorganization of the immigrant group, instability of social relations, and of various types of norm-breaking, juvenile delinquency, crime etc. is strongest among those groups whose cultural and educational standards are much lower than those of the absorbing society.' (Eisenstadt, 1954, 261) ${ }^{2}$

Deze beweringen gaan ten volle op voor de emigratie van Marokko naar Nederland. De sociaaleconomische afstand van het Marokkaanse platteland tot de urbane samenleving in Nederland is groot. Er zijn in ruraal Marokko welbewust ongeschoolde arbeiders geworven om in Nederland de laagst gekwalificeerde arbeid te verrichten, en dat laatste gold ook voor degenen die op eigen initiatief kwamen (zie Van Amersfoort \& Van der Wusten, 1975). ${ }^{3}$ Marokkanen die uit de

2 We zouden nu niet meer spreken van 'lower standards', zoals Eisenstadt deed.

3 Twee derde van alle immigranten, en daarbij rekenen wij ook de kleinere steden Al Hoceima en Nador, is afkomstig van het platteland. Het overblijvende derde deel van de migranten komt uit de stad. In volgorde van belangrijkheid als leverancier van emigranten zijn dit de steden Tetouan, Ouarzazate, Casablanca en Tanger. Kleinere aantallen immigranten (minder dan 10.000) zijn afkomstig uit de steden Chefchaouen, Meknès, Marrakech, Rabat, Larache en Kenitra. 
stad afkomstig waren, hadden wel een hoger opleidingspeil (Shadid, 1979). Ofschoon de volgende generaties Marokkanen in Nederland gemiddeld beter geschoold zijn dan de oorspronkelijke immigranten (Gijsberts \& Iedema, 2012), is het niet gewaagd te veronderstellen - maar onderzoek daarnaar is ons niet bekend - dat het sociaaleconomisch verschil tussen migranten van het platteland en de stad in Marokko zich in de volgende generaties heeft voortgezet. Bouras $(2012,52)$ schrijft in haar geschiedenis van Marokkanen in Nederland dat mensen van het platteland veel grotere gezinnen hadden dan in de stad en dat zij vanuit hun traditionele bestaan een grotere sprong moesten maken om in Nederland te aarden dan degenen die uit de stad kwamen. In de literatuur over de Marokkaanse emigratie worden voorbeelden genoemd van analfabete vrouwen die in Europa voor het eerst van hun leven een stad meemaakten en die de grootste moeite hadden met de moderniteit. Hoe moesten ze in die omgeving hun kinderen opvoeden (Bouhalhoul \& Van der Zwaard, 1996)? Pels (1998) schrijft daarover dat ouders gebukt gingen onder 'opvoedingsverlegenheid'. Dat het contrast van ontwikkelingsniveau in de twee landen tot gedragsproblemen van hun gezinsleden zou kunnen leiden, werd ook door de migrantenvaders wel degelijk ingezien. Ze voorzagen dat hun kinderen blootgesteld zouden worden aan de 'verdorvenheid van het Westen' en hebben zich om deze reden lang tegen gezinshereniging verzet (De Mas \& Haffmans, 1985; Van den Berg-Eldering, 1978).

Wanneer de sociaaleconomische afstand bepalend is voor de mogelijkheid deze te overbruggen, zou men verwachten dat de Marokkanen met een migratieachtergrond op het platteland vaker crimineel gedrag ontwikkelen dan degenen met een stedelijke achtergrond. Dit zou erop wijzen dat de criminaliteit ten minste voor een deel wordt veroorzaakt door omstandigheden in Marokko. Op grond van de theorie van sociale desorganisatie kunnen de volgende hypothesen worden opgesteld:

(H1a) De criminaliteitscijfers in Nederland zijn hoger onder de Marokkanen die zelf of wier ouders afkomstig zijn van het platteland dan onder hen die zelf of wier ouders uit de stad in Marokko afkomstig zijn.

(H1b) Het platteland-stadverschil in criminaliteit is het grootst onder de tweede generatie, het kleinst onder de eerste generatie; de anderhalve generatie neemt een tussenpositie in.

(H1c) Het platteland-stadverschil in criminaliteit neemt af na correctie voor verschillen in sociaaleconomische situatie in Nederland.

\subsection{Regionale specificiteit: achtergrond in de Rif}

Het is achteraf enigszins verbazend dat de sociologen van Chicago in de jaren twintig weinig oog hadden voor het ontwikkelingsniveau en de culturele en politieke specificiteit van de landen en landstreken waar de immigranten vandaan kwamen. De nationale of regionale achtergrond van de immigratie werd min of meer als gegeven beschouwd. Toch lag het voor de hand dat hun criminaliteitsprofiel nog wel iets zou laten zien van de criminaliteit van vroeger thuis. Zo vielen de (Zuid-)Italianen van de eerste generatie op door een relatief hoog aantal levensdelicten en de Finnen door misdaad die direct te maken had met overvloedig alcoholgebruik. Sutherland (1939) beredeneerde dat immigranten daarmee 
iets van de tradities van hun land hadden meegenomen. Maar dat eigen criminaliteitsprofiel zou snel vervagen vanaf het ogenblik dat jongeren opgroeiden in de steden van de Verenigde Staten. Voor Amerikanen was de differentiatie van Europa in de vorm van nationale staten al specifiek genoeg. De uitspraak van Sutherland over het criminaliteitsprofiel per groep had voorts impliciet verondersteld dat de immigranten een dwarsdoorsnede van de bevolking vormden van het land waar zij vandaan kwamen. Emigratie is altijd selectief, elk emigratieland kende zijn eigen expulsiegebieden met zijn eigen eventuele criminaliteitsproblemen. Immigranten uit Sicilië confronteerden de Amerikanen bijvoorbeeld met heel andere criminaliteit dan landverhuizers die uit het noorden van Italië afkomstig waren.

Onderzoekers van Chicago in de jaren twintig hadden natuurlijk wel opgemerkt dat de ene etnische groep meer sociale desorganisatie vertoonde dan de andere, ook al was hun sociaaleconomische status gelijk. Ze drukten dit uit door te schrijven dat groepen zich aan desorganisatie konden onttrekken door hun sociale cohesie te bewaren of door een 'kolonie' of een 'getto' te vormen (Park e.a., 1967, 107). Ook dit inzicht is nog steeds bruikbaar. Aronowitz (2002) paste dit inzicht toe om de effectiviteit van de sociale controle ten opzichte van jeugddelinquenten binnen de Turkse gemeenschap in Berlijn te beschrijven. Binnen de gemeenschap zag men kans om hun traditionele mechanismen van sociale controle in stand te houden. In Nederland is deze redenering gevolgd om het opmerkelijke verschil tussen de verhoudingsgewijs lage criminaliteitscijfers van de Turkse en de hoge misdaadcijfers van de Marokkaanse jongens te verklaren (Engbersen e.a., 1999). De sociaaleconomische positie en ook het resultaat in het onderwijs in beide groepen verschillen niet zoveel, maar de criminaliteit doet dat wel.

Het importmodel waarbij aan nationale en regionale herkomstverschillen in de analyse van de oorzaken van criminaliteit van de tweede generatie aandacht wordt geschonken, kan aan inzicht winnen door de specificiteit van het herkomstgebied te beschrijven met behulp van het begrip sociaal kapitaal. Deze term wordt gebruikt om het welvaartspeil en de ontwikkelingspotentie van een bevolking te begrijpen. Er is weinig sociaal kapitaal aanwezig wanneer mensen individueel of in gezins- of familieverband primair uit zijn op niet veel meer dan materieel gewin en voordeel op korte termijn. Sterk individualisme of familisme levert weinig sociale controle op waarmee crimineel gedrag wordt voorkomen. Sociaal kapitaal is in ruime mate aanwezig wanneer mensen binnen het netwerk van hun onderlinge relaties in staat zijn gemeenschappelijke actie te ondernemen en die tot een sociaaleconomisch succes te maken. Samenwerking berust op onderling vertrouwen, het delen van gemeenschappelijk bezit en op wederzijdse verantwoordelijkheid. Kortom: als in een bevolkingsgroep sociaal kapitaal aanwezig is, kan dit zich uiten in sociale controle, die sociaaleconomisch succes bevordert en crimineel gedrag voorkomt. De hoeveelheid sociaal kapitaal kent (grote) regionale variatie (Malecki, 2012).

Marokkaanse immigranten in Nederland zijn in meerderheid afkomstig uit het Rifgebergte. De hoeveelheid sociaal kapitaal onder de bevolking is hier notoir gering. De Mas heeft in een reeks publicaties de bevindingen van zijn veldwerk uiteengezet (zie De Mas, 1987). Hij verklaart met de theorie van sociaal kapitaal 
het contrast in streekmentaliteit, de ondernemingslust, de mate van economische voorspoed en de integratie in de nationale staat tussen de zuidelijke Souss en het noordelijke Rifgebergte in Marokko. Er zijn volgens hem geografische en historische redenen voor het achterblijven van speciaal de Rif in het ontwikkelingsproces (De Mas, 2001). Met zijn steile rotskusten is de Rif voor de machthebbers altijd een bufferzone tegen de invallen uit het noorden geweest in plaats van een integraal onderdeel van het land. Tot voor kort was de Rif het armste deel van het land. In de periode waarin Marokko gekoloniseerd was door de Fransen (1912 tot 1956) was de Rif Spaans en bleef onderontwikkeld. De bevolking spreekt een van de Berberse talen, Spaans en Marokkaans-Arabisch, maar geen Frans. Het gebied vormt van oorsprong een stammensamenleving. Het wordt echter niet door Berbers bestuurd, maar door Arabische ambtenaren. Na de onafhankelijkheid heeft koning Hassan II 'een ronduit vijandige relatie' met zijn onderdanen in deze streek ontwikkeld door opstanden in 1958-1959 hardhandig te onderdrukken (De Boer, 2013). In de criminologische literatuur over het vraagstuk van de Marokkaanse jeugddelinquentie (Van Gemert, 1998; Werdmölder, 2005) en in de media wordt impliciet of expliciet aangenomen dat de Riffijnse achtergrond van de Marokkaanse immigranten in Nederland voor een belangrijk deel verantwoordelijk is voor de hoge criminaliteitscijfers. Vooral het wederzijdse wantrouwen van families tegenover elkaar, dat corrigerende sociale controle over de jongeren bemoeilijkt, wordt hierin breed uitgemeten. Voor de Nederlandse overheid zijn deze inzichten al heel vroeg aanleiding geweest om voor een beter begrip van de criminaliteit van Marokkaanse jongens speciaal op hun achtergrond in de Rif acht te slaan (zie Leuw, 1997; Werdmölder \& Meel, 1993).

Ook op grond van het importmodel waarbij wordt gelet op de regionale specificiteit en de welvaart van de streek in het land van herkomst, kan worden beredeneerd dat de anderhalve generatie een tussenpositie inneemt: minder crimineel gedrag dan de tweede generatie, maar meer crimineel dan de eerste. In de jaren waarin de Marokkaanse gezinshereniging plaatsvond, werd door Nederlandse onderzoekers een debat gevoerd over de ontsporingsrisico's van de anderhalve generatie. Begon de criminaliteit (het was toen nog gebruikelijk om van 'marginalisering' of 'randgroepvorming' te spreken) van jonge migranten al vóór hun vertrek of pas na vestiging in Nederland? Werdmölder (1986) en Kaufman en Verbraeck (1986) meenden dat jongeren die als anderhalve generatie naar Nederland kwamen, al waren ontspoord in Marokko. Dat heeft te maken met het Marokkaanse patroon van opvoeden en speciaal in het Berbergebied van de Rif. De opvoeding van kleine kinderen gebeurt door moeder, maar vanaf het achtste levensjaar gaat de verantwoordelijkheid over op vader. Jongens gaan dan deel uitmaken van de mannenwereld en verblijven een groot deel van de dag buitenshuis. Men kan ze vinden op school, zwervend op straat en op de markt. Nu vader in Europa verbleef, ontbrak zijn strenge corrigerende hand. Voor moeders die hun greep op hun zonen dreigden te verliezen, vormde de (dreigende) ontsporing een belangrijk motief om erop aan te dringen het gezin in Europa te herenigen (Van 
den Berg-Eldering, 1978). ${ }^{4}$ In Nederland viel de sociale controle, voor zover die in Marokko nog had gewerkt, nog meer weg.

Op grond van het importmodel kunnen de volgende hypothesen worden opgesteld:

(H2a) De criminaliteitscijfers in Nederland zijn hoger onder de Marokkanen die zelf of wier ouders afkomstig zijn uit de Rif dan onder hen die zelf of wier ouders van elders in Marokko afkomstig zijn.

(H2b) Het Rif-eldersverschil in criminaliteit is het grootst onder de tweede generatie, het kleinst onder de eerste generatie; de anderhalve generatie neemt een tussenpositie in.

(H2c) Het Rif-eldersverschil in criminaliteit neemt af na correctie voor verschillen in sociaaleconomische situatie in Nederland.

\section{Onderzoeksopzet: data en methoden}

\subsection{Data}

De analyses zijn uitgevoerd met behulp van gegevens uit het Stelsel van Sociaalstatistische Bestanden (SSB) van het CBS. Het SSB bevat nagenoeg integrale data over de Nederlandse bevolking en is een stelsel van koppelbare registers en enquêtes die onderling op elkaar zijn afgestemd en consistent zijn gemaakt (zie Bakker, 2009; Bakker e.a., 2014). Het SSB bevat gegevens over onder meer demografie, onderwijs, arbeidsmarkt en criminaliteit. De criminaliteitsgegevens zijn afkomstig uit het HKS, een landelijk dekkend informatiesysteem van de politie dat sinds 1986 in gebruik is om verdachten van misdrijven te registreren. De herkomstregio van eerste en tweede generatie migranten is geen standaardinformatie in het SSB. Voor het onderzoek kon echter gebruik worden gemaakt van de uitkomsten van een project waarin eerste en tweede generatie Marokkanen, die op 1 januari 2009 in Nederland woonachtig waren, naar geboorteregio en geboorteprovincie zijn geclassificeerd (Fokkema e.a., 2009). Voor de tweede generatie waarvan beide ouders uit Marokko afkomstig zijn, is de herkomstregio van de moeder bepalend.

Het onderzoek richt zich op mannen van Marokkaanse herkomst in de leeftijdsgroep 15-25 jaar, die op peildatum 24 september 2010, maar ook aan het begin

4 Van Gelder en Sijtsma (1988) en Viskil (1999) vonden daarentegen dat er vóór de overkomst naar Nederland weinig aan de hand was geweest. De afwezigheid van vader was helemaal niet zo problematisch geweest omdat zijn rol was overgenomen door andere volwassen mannen in de familie of oudste zonen. Men moet wel bedenken dat deze migranten afkomstig waren uit gebieden waar al generaties lang een traditie van emigratie of seizoensarbeid bestond en waar men geleerd had om voor deze opvoedings- en gezagsproblemen oplossingen te vinden. 
van 2009 in Nederland woonachtig waren. ${ }^{5},{ }^{6}$ De onderzoekspopulatie betreft in totaal 32.400 15-25-jarige Marokkaanse mannen. Het onderzoek beperkt zich tot mannen omdat het percentage van misdrijven verdachte Marokkaanse mannen ruim vijf keer zo groot is als dat van Marokkaanse vrouwen (Jennissen \& Besjes, 2012, 176-177). We hebben gekozen voor de leeftijdsgroep 15-25 omdat voor het Marokkaanse bevolkingsdeel de verdachtenpercentages verreweg het grootst zijn in deze leeftijdscategorie (Jennissen \& Besjes, 2012, 177).

\subsection{Meetinstrumenten}

Of men ooit verdachte is geweest van een delict is de afhankelijke variabele. Onder ooit verdachte wordt verstaan een persoon tegen wie minstens eenmaal in diens leven (tot aan de peildatum van 31 december 2010) een proces-verbaal van aanhouding is opgemaakt op verdenking van een delict. Men dient zich te realiseren dat het laatst gepleegde delict geruime tijd voor genoemde peildatum kan hebben plaatsgevonden. Om een voorbeeld te noemen: het kan voorkomen dat de persoon in 201025 jaar is geworden, maar dat het delict plaatshad toen die nog maar 16 jaar oud was. De gegevens betreffen verdachten en geen veroordeelden, hoewel naar schatting meer dan 90 procent van de van een delict verdachte personen uiteindelijk een regeling aangeboden krijgt door het Openbaar Ministerie of in een later stadium krachtens een rechterlijke uitspraak wordt veroordeeld (Jennissen \& Blom, 2007). Het percentage ooit verdachte in de leeftijdscategorie 15-25 jaar bedraagt 50,5 procent (zie tabel 1), met andere woorden meer dan de helft van onze onderzoekspopulatie is tijdens hun leven ooit verdacht geweest van een misdrijf. De delicten waar het om gaat, variëren van zedendelicten, geweldsmisdrijven en overtredingen van de Opiumwet tot verkeers- en vermogensmisdrijven en schending van de openbare orde.

De onafhankelijke variabele waar onze interesse naar uitgaat, is de regionale herkomst van de Marokkanen. In eerdergenoemd onderzoek van Fokkema e.a. (2009) zijn de geboorteplaatsen van de Marokkaanse ingezetenen van Nederland naar de 16 administratieve regio's en, binnen de regio's, de 61 administratieve provincies gecodeerd (zie figuur 1). ${ }^{7}$ Voor ruim 95 procent van hen kon de her-

5 Onder mannen van Marokkaanse herkomst worden in dit artikel mannen aangeduid die in Marokko geboren zijn en van wie minstens een van de ouders ook in het buitenland geboren is (de eerste generatie), en verder personen die in Nederland geboren zijn, maar van wie de moeder in Marokko geboren is, of als de moeder Nederland als geboorteplaats heeft en de vader in Marokko geboren is (de tweede generatie). Voor de leesbaarheid wordt de onderzoeksgroep regelmatig verkort beschreven, verwijzend naar de herkomstgroepering, bijvoorbeeld Marokkaanse mannen, Marokkanen of Marokkaans. Dit verwijst dan altijd naar de zojuist beschreven afbakening naar herkomst en niet naar nationaliteit.

6 De selectiedatum 24 september 2010 is tevens de peildatum voor demografische en sociaaleconomische kenmerken (standgegevens) van de onderzoeksdoelgroep. Criminaliteitsgegevens zijn van iets latere datum: 31 december 2010. De aanvullende eis dat de betreffende groep ook aan het begin van 2009 in Nederland gewoond moet hebben, heeft ermee te maken dat van de meesten van hen de herkomstregio en -provincie in Marokko bekend is.

7 Registratie van de geboorteplaats van niet-Nederlanders vindt plaats wanneer men zich in Nederland inschrijft, door het tonen van een paspoort of geboorteakte aan de dienstdoende ambtenaar. 


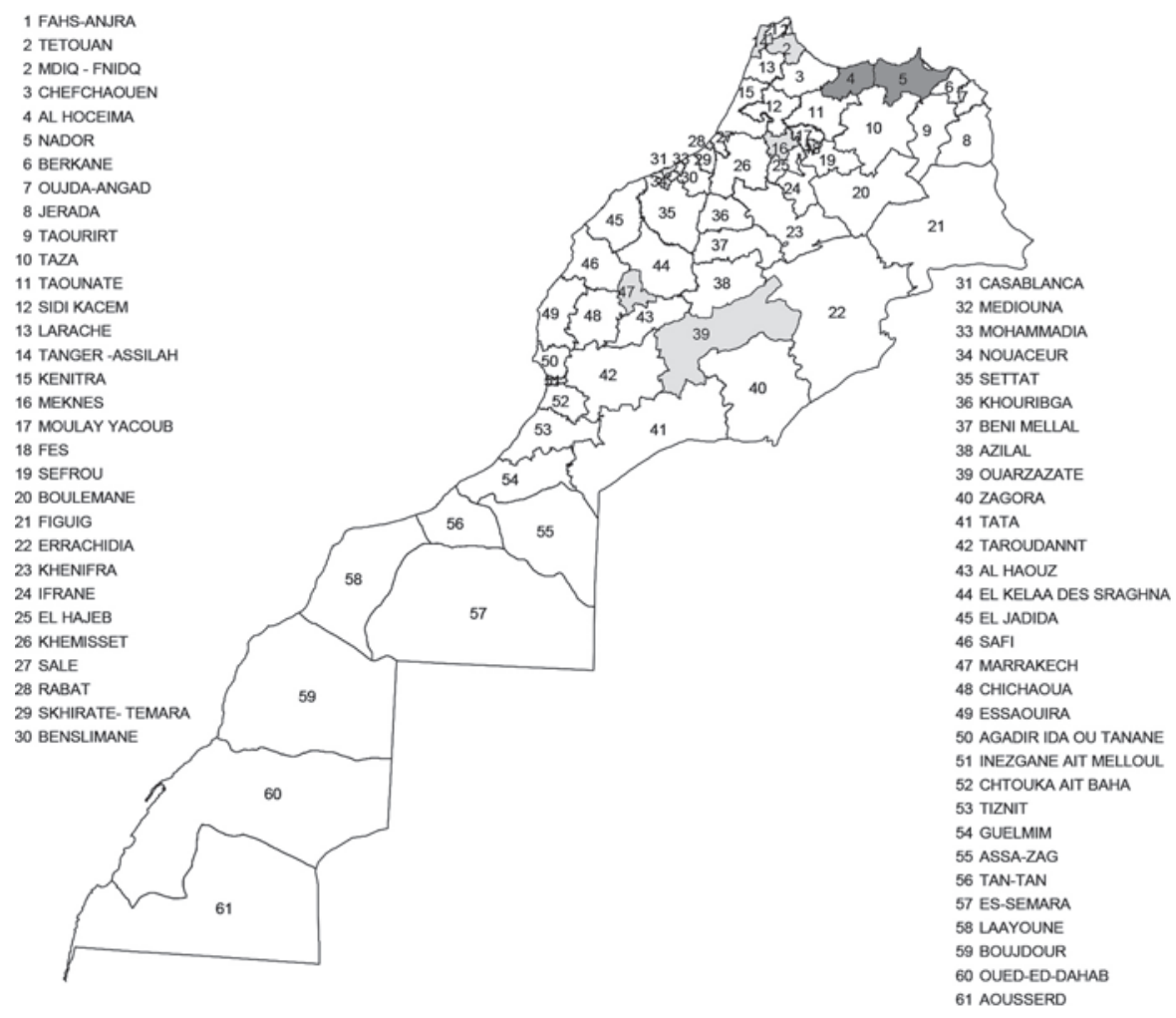

Vanwege het ontbreken van bevolkingsgegevens van Mdiq-Fnidq is deze provincie samengevoegd met Tetouan.

\section{Figuur 1 Landkaart Marokko}

komstregio en -provincie in Marokko worden vastgelegd. Voor de 15-25-jarige Marokkaanse mannen in ons onderzoeksdatabestand is het percentage onbekende herkomstregio en -provincie 2 procent. Ter toetsing van hypothese 1a zijn de (provincies met als voornaamste) steden Casablanca, Fès, Marrakech, Meknès, Ouarzazate, Rabat, Tanger en Tetouan onderscheiden van de overige (plattelands)gebieden. Voor toetsing van hypothese 2a zijn de herkomstprovincies opgesplitst in 'het Rifgebied' - de provincies Al Hoceima en Nador - en 'Overig' - de overige 59 provincies. Marokkanen met een migratieachtergrond uit de stedelijke provincies respectievelijk buiten de Rif vormen de referentiegroep. Het is van belang hier op te merken dat het Rifgebied en de gebruikte administratieve provincies Al Hoceima en Nador niet naadloos op elkaar aansluiten; het bovenste deel van de provincies Taounate en Taza behoort feitelijk tot het Rifgebied (zie figuur 2).

Om te controleren voor mogelijke demografische compositieverschillen tussen de onderscheiden herkomstgebieden, zijn in het onderzoek de volgende variabelen gebruikt: leeftijd, positie in het huishouden en mate van stedelijkheid van de hui- 


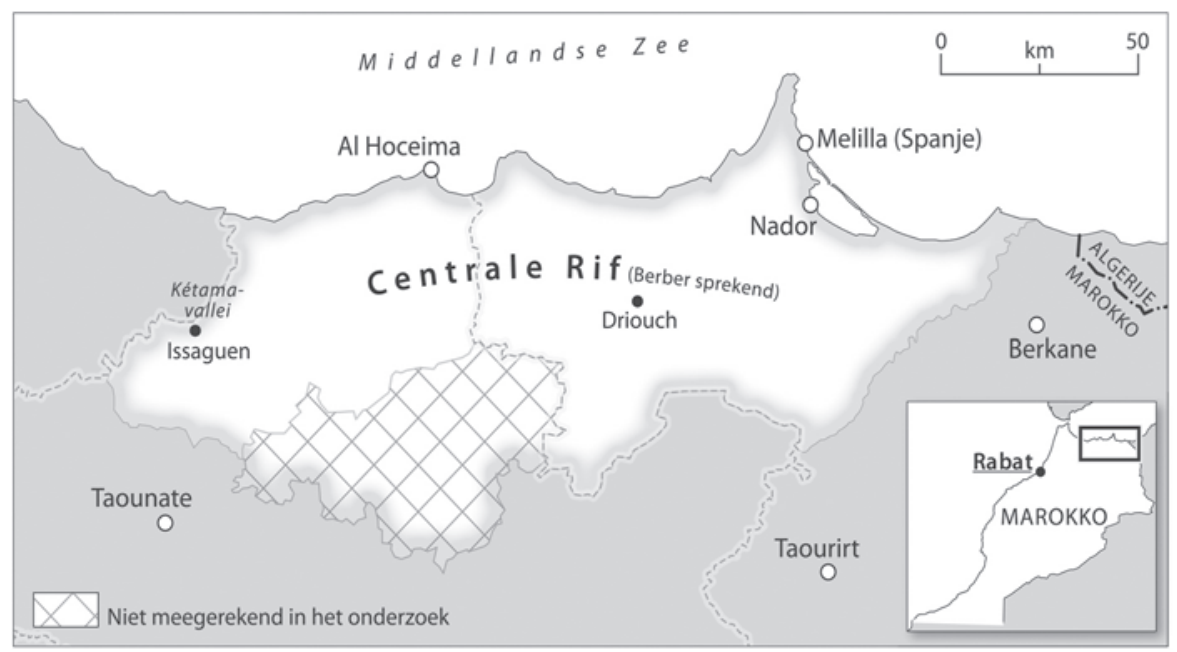

Figuur 2 Het Rifgebied

dige woonplaats. Om te achterhalen of er voor leeftijd sprake is van een nietlineair verband, is naast deze variabele ook het kwadraat ervan in de analyse meegenomen. Voor de positie in het huishouden is onderscheid gemaakt tussen kinderen en overige huishoudensleden die deel uitmaken van een tweeouderhuishouden (referentiegroep) of van een eenouderhuishouden. Verder worden onderscheiden: alleenstaanden, partners in (echt)paren zonder kinderen en partners in (echt)paren met kinderen. Er is nog een gemêleerde categorie 'overig', die bestaat uit alleenstaande ouders, personen in instellingen en tehuizen, en enkele andere restgroepen. Wat de mate van stedelijkheid betreft, zijn de volgende categorieën onderscheiden: zeer sterk stedelijk, sterk stedelijk, matig stedelijk en weinig tot niet stedelijk (de referentiegroep).

Om hypothesen $1 b$ en $2 b$ te toetsen zijn drie generaties onderscheiden: de eerste generatie (referentiegroep), de anderhalve generatie en de tweede generatie. De anderhalve generatie betreft de eerste generatie die op jonge leeftijd naar Nederland is gekomen en daar een groot deel van haar opvoeding en opleiding heeft genoten. In ons artikel is als leeftijdsgrens voor immigratie de leeftijd van 12 jaar gekozen. De anderhalve generatie heeft in een aantal opzichten meer overeenkomsten met de tweede dan met de eerste generatie (Rumbaut, 2004).

Tot slot, ter toetsing van hypothesen $1 c$ en $2 c$, zijn drie indicatoren voor sociaaleconomische status in de analyse meegenomen: opleiding, besteedbaar huishoudensinkomen en voornaamste inkomstenbron. Bij de variabele opleiding gaat het om het hoogste niveau waarin de persoon een opleiding gevolgd heeft, die niet noodzakelijk met een diploma is afgesloten. Het kan zijn dat de persoon nog bezig is met de studie, of dat die niet geslaagd is voor het afsluitend examen. De reden om uit te gaan van het hoogst gevolgde opleidingsniveau in plaats van het hoogst behaalde niveau hangt samen met de leeftijd van de onderzoeksgroep, waarvan 
velen nog schoolgaand of studerend zijn. ${ }^{8}$ Er wordt onderscheid gemaakt tussen laag (waaronder basisonderwijs, vmbo, mbo 1 en de onderbouw van havo en vwo), middelbaar (waaronder mbo 2-4 en bovenbouw havo en vwo), de referentiegroep hoog (waaronder hbo en wo propedeuse, bachelor (kandidaatsexamen), master (doctoraalexamen) en het doctoraat) en onbekend. Voor de Marokkaanse jongemannen van 15 tot 25 jaar is het percentage opleidingsniveau onbekend slechts 5,3 procent (tabel 1). Het besteedbaar huishoudensinkomen betreft het gezamenlijk bruto-inkomen van alle huishoudensleden verminderd met premies, belastingen en enkele betaalde inkomensoverdrachten, zoals alimentatie voor de voormalige echtgeno(o)t(e). De huishoudens waar de 15-25-jarige Marokkaanse mannen toe behoren en waarvan het besteedbaar huishoudensinkomen op jaarbasis bekend is in de administraties worden in 25 procent-groepen van de inkomensverdeling gepresenteerd. ${ }^{9}$ Huishoudens waarvan in de databron geen inkomen bekend is, worden buiten de inkomensverdeling gehouden. Om de inkomens vergelijkbaar te maken voor verschillende grootte en samenstelling van de huishoudens wordt het besteedbaar inkomen gestandaardiseerd weergegeven, hetgeen wil zeggen gecorrigeerd met een equivalentiefactor. ${ }^{10}$ De voornaamste inkomstenbron wordt op basis van zwaartepunt van de inkomstensoort bepaald. De indeling naar voornaamste inkomstenbron onderscheidt: (1) betaalde banen van werknemers en zelfstandigen (incl. freelance-inkomsten e.d.; de referentiegroep), (2) uitkeringen (bijstands-, werkloosheids- en arbeidsongeschiktheidsuitkering en overige uitkeringen), (3) scholier/student (alle personen t/m 15 jaar en alle onderwijsvolgende personen van ouder dan 15 jaar die naast een eventuele studiebeurs hooguit 70 procent van het minimumloon incl. vakantie-uitkering als neveninkomsten hebben) en (4) overig (personen met geen of geen bekende inkomstenbron op peilmoment; hier horen ook personen met alimentatie, een ouderlijke toelage of vermogensinkomsten toe, want dergelijke inkomsten tellen niet mee voor het bepalen van het zwaartepunt).

De standgegevens, zoals sociaaleconomische status en leeftijd, hebben als peildatum vrijdag 24 september 2010. De volumegegevens, zoals het besteedbaar huishoudens(jaar)inkomen, hebben betrekking op het jaar 2010.

8 In de groep van Marokkaanse mannen van 15 tot 25 jaar, van wie het opleidingsniveau bekend was, hadden 20.800 van de 30.700 mannen niveau laag als hoogst behaald, maar 13.700 van hen hadden een middelbare opleiding gevolgd of waren op peildatum nog onderwijsvolgend.

9 De klassengrenzen van de 25 procent-groepen van het gestandaardiseerd besteedbaar huishoudensinkomen op jaarbasis zijn gerangschikt van laag naar hoog: 11.877 euro, 15.209 euro en 20.135 euro.

10 In de equivalentiefactor komen de schaalvoordelen tot uitdrukking die het gevolg zijn van het voeren van een gemeenschappelijke huishouding. Er is gebruik gemaakt van de CBS-equivalentieschaal, waarbij het eenpersoonshuishouden als standaardhuishouden is gekozen met factor 1 . Voor iedere volgende meerderjarige voegt de CBS-equivalentieschaal een factor van 0,37 toe. Voor minderjarige kinderen is dat afhankelijk van de rangorde in het huishouden een toegevoegde factor van tussen 0,15 en 0,33. Een alleenstaande met 10.000 euro inkomen bevindt zich dus op hetzelfde welvaartsniveau als het kinderloze echtpaar met een inkomen van 13.700 euro (gestandaardiseerd is dat 10.000 euro). 
Tabel 1: Beschrijvende statistieken 15-25-jarige Marokkaanse mannen

\begin{tabular}{|c|c|c|}
\hline & $\%$ & M \\
\hline \multicolumn{3}{|l|}{ Criminaliteit } \\
\hline Ooit verdacht & 50,5 & \\
\hline \multicolumn{3}{|l|}{ Herkomst } \\
\hline stad & 29,7 & \\
\hline platteland & 68,2 & \\
\hline onbekend & 2,0 & \\
\hline Rif & 44,8 & \\
\hline Al Hoceima & 13,9 & \\
\hline Nador & 30,8 & \\
\hline niet-Rif & 53,2 & \\
\hline onbekend & 2,0 & \\
\hline \multicolumn{3}{|l|}{ Demografische kenmerken } \\
\hline Leeftijd & & 19,75 \\
\hline \multicolumn{3}{|l|}{ Huishoudenspositie } \\
\hline thuiswonend kind of overig lid (geen ouder) in tweeouderhuishouden & 52,7 & \\
\hline thuiswonend kind of overig lid (geen ouder) in eenouderhuishouden & 14,0 & \\
\hline alleenstaande & 17,5 & \\
\hline (on)gehuwd partner in paar zonder kinderen & 4,0 & \\
\hline (on)gehuwd partner in paar met kinderen & $\mathrm{I}, \mathrm{I}$ & \\
\hline overig & 10,6 & \\
\hline \multicolumn{3}{|l|}{ Mate van stedelijkheid } \\
\hline zeer sterk & 53,2 & \\
\hline sterk & 26,8 & \\
\hline matig & 14,0 & \\
\hline weinig/niet & 6,0 & \\
\hline onbekend & 0,1 & \\
\hline \multicolumn{3}{|l|}{ Generatie } \\
\hline I & 4,9 & \\
\hline $\mathrm{I}, 5$ & $\mathrm{II}, 7$ & \\
\hline 2 & 83,3 & \\
\hline \multicolumn{3}{|l|}{ Sociaaleconomische status } \\
\hline \multicolumn{3}{|l|}{ Opleiding } \\
\hline laag & 21,8 & \\
\hline middelbaar & 55,6 & \\
\hline hoog & 17,3 & \\
\hline onbekend & 5,3 & \\
\hline \multicolumn{3}{|l|}{ Gestandaardiseerd besteedbaar huishoudensinkomen } \\
\hline onbekend & 2,4 & \\
\hline
\end{tabular}


Tabel 1: (Vervolg)

\begin{tabular}{lcc}
\hline & $\%$ & $\mathbf{M}$ \\
\hline 0 tot 25\%-groep & 24,4 & \\
25 tot 50\%-groep & 24,4 & 24,4 \\
50 tot 75\%-groep & 24,4 \\
75 tot 100\%-groep & \\
Voornaamste inkomstenbron & 25,2 \\
betaalde baan & 7,7 \\
uitkering & 56,2 \\
scholier/student & 10,9 \\
overig & \\
\hline
\end{tabular}

Bron: CBS.

\section{Resultaten}

Met behulp van logistische regressieanalyse is berekend hoe groot het nettoeffect is van regionale herkomst in Marokko op het ooit verdacht zijn van een misdrijf. De resultaten staan weergegeven in tabel 2 en 3. In Model 1 is alleen de regionale herkomst in de analyse opgenomen. 15-25-jarige Marokkanen (met ouders) van respectievelijk het platteland en de Rif hebben een grotere kans ooit verdacht geweest te zijn van een delict dan degenen met een stedelijke achtergrond respectievelijk een buiten het Rifgebied. ${ }^{11} \mathrm{Om}$ uit te sluiten dat deze herkomstverschillen voortkomen uit demografische compositieverschillen, is in Model 2 gecorrigeerd voor drie demografische kenmerken waarvan uit eerder onderzoek is gebleken is dat zij invloed hebben op crimineel gedrag: leeftijd, huishoudenspositie en mate van stedelijkheid van de huidige woonplaats. Er is sprake van een omgekeerd U-vormig verband tussen leeftijd en criminaliteit: de kans om ooit als verdachte te zijn aangemerkt, neemt eerst toe met de leeftijd, om op ongeveer 22-jarige leeftijd weer af te nemen. 15-25-jarige Marokkanen die als kind of overig lid (geen ouder) deel uitmaken van een tweeouderhuishouden hebben een lagere kans om ooit verdacht geweest te zijn van criminaliteit dan hun leeftijdsgenoten in een andere leefvorm, met uitzondering van degenen die zonder kinderen met een partner samenwonen. Enigszins opvallend is het negatieve verband tussen criminaliteit en de mate van stedelijkheid van iemands woonplaats. De belangrijkste bevinding uit Model 2 is echter dat na deze correctie de herkomstverschillen zelfs iets groter zijn. Hypothesen 1a en 2a worden hiermee bevestigd: de criminaliteitscijfers in Nederland zijn hoger onder de Marokkanen die zelf of wier ouders afkomstig zijn van het platteland respectievelijk de Rif dan

11 Omwille van de leesbaarheid wordt gesproken van de kans om ooit verdacht geweest te zijn van criminaliteit, terwijl de correcte interpretatie van de odds is: de kans om ooit verdacht geweest te zijn van criminaliteit ten opzichte van de kans om nimmer als verdachte te zijn aangemerkt. De odds ratio is de verhouding van twee odds. 
van hen die zelf of wier ouders uit de stedelijke provincies respectievelijk buiten het Rifgebied in Marokko afkomstig zijn.

De invloed van iemands herkomst op crimineel gedrag dient echter serieus te worden gerelativeerd. De verschillen in regionale herkomst zijn weliswaar significant, maar klein: na controle voor de drie demografische kenmerken is de kans 1,138 groter dat 15-25-jarige Marokkanen met een plattelandsachtergrond ooit verdachte zijn geweest van een delict, 15-25-jarige Marokkanen met hun roots in de Rif hebben een 1,106 keer zo grote kans om in de criminaliteitsstatistieken voor te komen. De geringe invloed van iemands regionale herkomst op de kans om als verdachte geregistreerd te staan, komt ook tot uiting in het lage percentage variantie dat door deze variabele wordt verklaard: de verklaarde variantie is niet meer dan 0,1 procent (zie Model 1). Dat het geringe effect toch significant is, heeft te maken met de grote omvang van de onderzoekspopulatie; bij grote onderzoekspopulaties worden vaak zelfs zwakke verbanden statistisch significant.

In Model 3 is de generatie als hoofdeffect toegevoegd en in Model 4, ter toetsing van hypothesen $1 b$ en $2 b$, ook als interactie-effect met iemands regionale herkomst. Er is sprake van een significant verschil tussen de eerste generatie enerzijds en de anderhalve en tweede generatie anderzijds. Degenen die voor hun twaalfde naar Nederland zijn gekomen of hier in Nederland zijn geboren, hebben een beduidend grotere kans ooit verdacht te zijn geweest van een misdrijf dan degenen die hun gehele jeugd in Marokko hebben doorgebracht. Toevoeging van de generatie verhoogt de verklaarde variantie met 0,3 procentpunt. Dit generatieverschil hangt echter niet samen met iemands regionale herkomst: geen van de voor deze studie relevante interactie-effecten zijn significant. ${ }^{12}$ We vinden dus geen ondersteuning voor hypothesen $1 \mathrm{~b}$ en $2 \mathrm{~b}$; ongeacht de generatie komen Marokkanen met een plattelands- respectievelijk Rif-achtergrond iets vaker voor in de criminaliteitsstatistieken.

Ter toetsing van hypothesen $1 c$ en $2 c$, die stellen dat de regionale herkomstverschillen zich manifesteren in sociaaleconomische verschillen in Nederland, zijn enkele sociaaleconomische kenmerken in het laatste model toegevoegd. Sociaaleconomische positie is een zeer belangrijke voorspeller voor crimineel gedrag, getuige de sterke toename van het verklaarde deel van de variantie (een toename van 12 procent). De kans op crimineel gedrag is aanzienlijk kleiner naarmate het opleidingsniveau en inkomen hoger zijn en bij het hebben van een betaalde baan. De regionale herkomstverschillen worden na toevoeging van deze sociaaleconomische verschillen weliswaar kleiner, maar blijven significant en de afname in effect is niet significant. Er is dus geen ondersteuning van hypothesen $1 c$ en 2c: het feit dat Marokkanen met een plattelands- respectievelijk Rif-achtergrond iets vaker ooit verdacht zijn geweest van crimineel gedrag houdt geen verband met een slechtere sociaaleconomische positie in Nederland.

12 De hoofdeffecten van de geografische-herkomstvariabelen in Model 4 verschillen licht (platteland, Rif) tot sterk (onbekend) met die in Model 2. Dit komt door toevoeging van de interactieeffecten, waardoor het hoofdeffect geldt voor één bepaalde groep, namelijk de eerste generatie Marokkanen. 
Tabel 2: $\quad$ Relatieve-kansverhoudingen (odds ratio's) voor het ooit verdacht zijn geweest van een delict, 15-25-jarige Marokkaanse mannen met een plattelands- versus stedelijke achtergrond

\begin{tabular}{|c|c|c|c|c|c|}
\hline Model: & I & 2 & 3 & 4 & 5 \\
\hline \multicolumn{6}{|l|}{ Herkomst (ref. stad) } \\
\hline platteland & $1,103 * * *$ & $\mathrm{I}, 138 * * *$ & $1,137 * * *$ & $\mathrm{I}, 072$ & $\mathrm{I},|\mathrm{O}| * * *$ \\
\hline onbekend & 0,970 & 0,901 & $0,90 \mathrm{I}$ & $0,326 * *$ & 0,879 \\
\hline \multicolumn{6}{|l|}{ Demografische kenmerken } \\
\hline Leeftijd (lineair) & & $3,062 * * *$ & $2,980 * * *$ & $2,977^{* * *}$ & $3,812^{* * *}$ \\
\hline Leeftijd-kwadraat & & $0,975 * * *$ & $0,976 * * *$ & $0,976^{* * *}$ & $0,972 * * *$ \\
\hline \multicolumn{6}{|l|}{$\begin{array}{l}\text { Huishoudenspositie (ref. thuis- } \\
\text { wonend kind of overig lid (geen } \\
\text { ouder) in tweeouderhuishouden) }\end{array}$} \\
\hline $\begin{array}{l}\text { thuiswonend kind of overig lid } \\
\text { (geen ouder) in eenouderhuishouden }\end{array}$ & & $1,298 * * *$ & $1,298 * * *$ & $1,297 * * *$ & $\mathrm{I}, 164 * * *$ \\
\hline alleenstaande & & $1,070 *$ & $\mathrm{I}, 077^{*}$ & I,076* & $\mathrm{I}, 025$ \\
\hline $\begin{array}{l}\text { (on)gehuwd partner in paar } \\
\text { zonder kinderen }\end{array}$ & & 1,020 & 1,025 & 1,028 & $1,14 I^{*}$ \\
\hline $\begin{array}{l}\text { (on)gehuwd partner in paar } \\
\text { met kinderen }\end{array}$ & & $1,336 * *$ & $1,339 * *$ & $1,342^{* *}$ & $\mathrm{I}, 244$ \\
\hline overig & & $1,232 * * *$ & $1,224 * * *$ & $1,222 * * *$ & $\mathrm{I}, 243^{* * *}$ \\
\hline \multicolumn{6}{|l|}{$\begin{array}{l}\text { Mate van stedelijkheid woon- } \\
\text { gemeente (ref. weinig/niet) }\end{array}$} \\
\hline zeer sterk & & $0,833 * * *$ & $0,844 * * *$ & $0,845^{* * *}$ & $0,870 * *$ \\
\hline sterk & & $0,889 *$ & $0,890 *$ & $0,890 *$ & $0,892 *$ \\
\hline matig & & $0,877^{*}$ & $0,875^{*}$ & $0,876 *$ & $0,878 *$ \\
\hline onbekend & & 1,256 & 1,285 & 1,332 & $0,428 *$ \\
\hline \multicolumn{6}{|l|}{ Generatie (ref. I) } \\
\hline $\mathrm{I}, 5$ & & & $1,574 * * *$ & $\mathrm{I}, 487^{* * *}$ & $2,422 * * *$ \\
\hline 2 & & & $1,597 * * *$ & $1,496 * * *$ & $2,653 * * *$ \\
\hline \multicolumn{6}{|l|}{ Generatie $x$ Herkomst } \\
\hline I,5+ platteland & & & & 1,050 & \\
\hline $2+$ platteland & & & & 1,066 & \\
\hline I,5+onbekend & & & & $3,923 * *$ & \\
\hline $2+$ onbekend & & & & $2,885^{*}$ & \\
\hline \multicolumn{6}{|l|}{ Sociaaleconomische status } \\
\hline \multicolumn{6}{|l|}{ Opleiding (ref. hoog) } \\
\hline laag & & & & & $5,669 * * *$ \\
\hline middelbaar & & & & & $3,336 * * *$ \\
\hline onbekend & & & & & $2,239 * * *$ \\
\hline
\end{tabular}

Gestandaardiseerd besteedbaar huishoudensinkomen (ref. $75 \mathrm{t} / \mathrm{m} \mathrm{100 \% )}$ 
Tabel 2: (Vervolg)

\begin{tabular}{|c|c|c|c|c|c|}
\hline Model: & $I$ & 2 & 3 & 4 & 5 \\
\hline 0 tot $25 \%$-groep & & & & & $1,738 * * *$ \\
\hline 25 tot 50\%-groep & & & & & $\mathrm{I}, 498 * * *$ \\
\hline 50 tot 75\%-groep & & & & & $\mathrm{I}, \mathrm{I} 180 * * *$ \\
\hline onbekend & & & & & $2,719 * * *$ \\
\hline \multicolumn{6}{|c|}{$\begin{array}{l}\text { Voornaamste inkomstenbron } \\
\text { (ref. betaalde baan) }\end{array}$} \\
\hline uitkering & & & & & $|, 5| 4 * * *$ \\
\hline scholier/student & & & & & 0,935 \\
\hline overig & & & & & $2,44 \mid * * *$ \\
\hline Nagelkerke R Square & 0,001 & 0,071 & 0,074 & 0,074 & 0,192 \\
\hline
\end{tabular}

* $p<0,05 ; * * p<0,0$ I; *** $p<0,00$ I.

Bron: CBS.

Tabel 3: Relatieve-kansverhoudingen (odds ratio's) voor het ooit verdacht zijn geweest van een delict, 15-25-jarige Marokkaanse mannen met een Rif-versus niet-Rif-achtergrond

\begin{tabular}{|c|c|c|c|c|c|}
\hline Model: & $\mathbf{I}$ & 2 & 3 & 4 & 5 \\
\hline \multicolumn{6}{|l|}{ Herkomst (ref. overig) } \\
\hline Rif & $\mathrm{I}, 074 * *$ & $1,106 * * *$ & $1,104 * * *$ & $\mathrm{I}, 249 *$ & $1,068 * * *$ \\
\hline onbekend & 0,936 & 0,863 & 0,862 & $0,34 I^{* *}$ & 0,847 \\
\hline \multicolumn{6}{|l|}{ Demografische kenmerken } \\
\hline Leeftijd (lineair) & & $3,056 * * *$ & $2,975 * * *$ & $2,977 * * *$ & $3,810 * * *$ \\
\hline Leeftijd-kwadraat & & $0,975 * * *$ & $0,976 * * *$ & $0,976 * * *$ & $0,972 * * *$ \\
\hline \multicolumn{6}{|l|}{$\begin{array}{l}\text { Huishoudenspositie (ref. } \\
\text { thuis wonend kind of overig lid } \\
\text { (geen ouder) in tweeouder- } \\
\text { huishouden) }\end{array}$} \\
\hline $\begin{array}{l}\text { thuiswonend kind of overig lid } \\
\text { (geen ouder) in eenouderhuishouden }\end{array}$ & & $1,298 * * *$ & $1,298 * * *$ & $1,296 * * *$ & $1,163 * * *$ \\
\hline alleenstaande & & $\mathrm{I}, 07 I^{*}$ & $\mathrm{I}, 078^{*}$ & $1,076^{*}$ & 1,026 \\
\hline $\begin{array}{l}\text { (on)gehuwd partner in paar } \\
\text { zonder kinderen }\end{array}$ & & 1,020 & 1,026 & 1,029 & $\mathrm{I}, \mid \mathrm{I} 2 *$ \\
\hline $\begin{array}{l}\text { (on)gehuwd partner in paar } \\
\text { met kinderen }\end{array}$ & & $1,336 * *$ & $1,339 * *$ & $1,342 * *$ & 1,246 \\
\hline overig & & $1,232 * * *$ & $1,224 * * *$ & $1,222 * * *$ & $1,243 * * *$ \\
\hline \multicolumn{6}{|l|}{$\begin{array}{l}\text { Mate van stedelijkheid woon- } \\
\text { gemeente (ref. weinig/niet) }\end{array}$} \\
\hline zeer sterk & & $0,833 * * *$ & $0,845 * * *$ & $0,846 * * *$ & $0,87 I^{* *}$ \\
\hline sterk & & $0,888^{*}$ & $0,889 *$ & $0,890 *$ & $0,891 *$ \\
\hline matig & & $0,876^{*}$ & $0,875^{*}$ & $0,876^{*}$ & $0,878^{*}$ \\
\hline onbekend & & 1,264 & 1,293 & 1,340 & $0,430 *$ \\
\hline
\end{tabular}


Tabel 3: (Vervolg)

\begin{tabular}{|c|c|c|c|c|c|}
\hline Model: & $I$ & 2 & 3 & 4 & 5 \\
\hline \multicolumn{6}{|l|}{ Generatie (ref. I) } \\
\hline $\mathrm{I}, 5$ & & & $1,570 * * *$ & $\mathrm{I}, 572 * * *$ & $2,428 * * *$ \\
\hline 2 & & & $1,596 * * *$ & $1,655^{* * *}$ & $2,654 * * *$ \\
\hline \multicolumn{6}{|l|}{ Generatie $x$ Herkomst } \\
\hline I,5 + Rif & & & & 0,935 & \\
\hline $2+$ Rif & & & & 0,871 & \\
\hline I,5+onbekend & & & & $3,708^{*}$ & \\
\hline $2+$ onbekend & & & & $2,608^{*}$ & \\
\hline \multicolumn{6}{|l|}{ Sociaaleconomische status } \\
\hline \multicolumn{6}{|l|}{ Opleiding (ref. hoog) } \\
\hline laag & & & & & $5,679 * * *$ \\
\hline middelbaar & & & & & $3,339 * * *$ \\
\hline onbekend & & & & & $2,242 * * *$ \\
\hline \multicolumn{6}{|c|}{$\begin{array}{l}\text { Gestandaardiseerd besteedbaar huis- } \\
\text { houdensinkomen (ref. } 75 \mathrm{t} / \mathrm{m} \text { 100\%) }\end{array}$} \\
\hline 0 tot $25 \%$-groep & & & & & $\mathrm{I}, 737 * * *$ \\
\hline 25 tot $50 \%$-groep & & & & & $\mathrm{I}, 496 * * *$ \\
\hline 50 tot $75 \%$-groep & & & & & $\mathrm{I}, 179 * * *$ \\
\hline onbekend & & & & & $2,717^{* * * *}$ \\
\hline \multicolumn{6}{|c|}{$\begin{array}{l}\text { Voornaamste inkomstenbron } \\
\text { (ref. betaalde baan) }\end{array}$} \\
\hline uitkering & & & & & $1,514 * * *$ \\
\hline scholier/student & & & & & 0,935 \\
\hline overig & & & & & $2,439 * * *$ \\
\hline Nagelkerke R Square & 0,000 & $0,07 \mid$ & 0,074 & 0,074 & 0,192 \\
\hline
\end{tabular}

$* \mathrm{p}<0,05 ; * * \mathrm{p}<0,01 ; * * * \mathrm{p}<0,001$.

Bron: CBS.

In de onderzoeksopzet is aangegeven dat de provincies Al Hoceima en Nador niet volledig het Rifgebied bestrijken. Derhalve is een extra analyse uitgevoerd waarbij ook de twee provincies ten zuiden van de Rif - Taounate en Taza - zijn vergeleken met de provincies elders in Marokko. Uit deze analyses blijkt dat ook Marokkanen die zelf of wier ouders afkomstig zijn uit deze provincies een bovengemiddelde kans hebben om als verdachte geregistreerd te staan (resultaten niet gepresenteerd). Ook hierbij geldt echter dat de effecten weliswaar significant, maar klein zijn. Een tweede, aanvullende analyse betreft de vergelijking van de herkomstprovincies Al Hoceima en Nador afzonderlijk met de overige provincies. Geen significant verschil doet zich voor in de verhoogde kans op het geregistreerd staan als verdachte tussen Marokkanen die hun roots hebben in Al Hoceima en degenen die zelf of wier ouders in Nador zijn geboren (resultaten niet gepresenteerd). Verder is in een eerder stadium onderzocht of de verschillen in criminaliteit naar 
regionale herkomst anders uitpakken wanneer alleen gekeken wordt naar de meer ernstige vormen van criminaliteit respectievelijk veelplegerschap. Ook dan speelt regionale herkomst een marginale rol (resultaten niet gepresenteerd).

\section{Conclusie}

Dit onderzoek wil een bijdrage leveren aan het beantwoorden van een belangrijke vraag in de sociologie van migratie en criminaliteit. In tegenstelling tot de eerste levert de tweede generatie van immigranten vaak een criminaliteitsprobleem op. De zogenaamde anderhalve generatie (kinderen die op jonge leeftijd zijn geïmmigreerd) neemt een tussenpositie in. Moet de oorsprong van dat probleem worden gezocht in de huidige sociaaleconomische en culturele positie die de immigrantengroep in het nieuwe land inneemt, of moet er voor de oorzaak ervan primair worden gekeken naar omstandigheden in het land van herkomst? Er wordt in de internationale criminologische literatuur gewoonlijk voor de eerste mogelijkheid gekozen. In de Nederlandse literatuur over allochtone jeugdcriminaliteit wordt daarentegen vaak naar factoren in het land van herkomst verwezen. Dat geldt niet alleen voor Marokkanen, maar ook voor Antillianen, Surinamers en andere bevolkingsgroepen.

De casus van de criminaliteit van Marokkanen in Nederland biedt een mogelijkheid om de tweede veronderstelling te toetsen. Wij beschikken over een omvangrijk databestand met informatie over de geboorteregio van (de ouders van) alle Marokkanen en de verdachtenregistraties uit het HKS van het KLPD. Met deze unieke dataset is na te gaan in hoeverre de mate waarin jongens van Marokkaanse afkomst met de politie in aanraking zijn gekomen, varieert met hun regionale herkomst of die van hun ouders in Marokko.

De veronderstelling dat regionale herkomst een rol speelt, laat zich beredeneren op grond van twee theoretische uitgangspunten:

a In aansluiting op de theorie van sociale desorganisatie kan worden voorspeld dat emigranten die van het platteland in Marokko terechtkomen in de stedelijke samenleving van Nederland, een grotere sociaaleconomische kloof moeten overbruggen dan degenen die uit de stad in Marokko afkomstig zijn.

b In aansluiting op het gezichtspunt van de regionale specificiteit en waar we kunnen spreken van relatief weinig sociaal kapitaal en disfunctioneren van het systeem van sociale controle, kan worden voorspeld dat vooral immigrantenkinderen met een achtergrond in de Rif een risicogroep opleveren.

De analyses laten verschillen in criminaliteit zien naar regionale herkomst: afkomst van het platteland respectievelijk de Rif in Marokko levert een hoger risico op om in Nederland met de politie in aanraking te komen. Statistische significantie is echter niet hetzelfde als relevantie. Regionale herkomst blijkt slechts heel weinig van de variatie in criminaliteitscijfers te verklaren, om precies te zijn: niet meer dan 0,1 procent. De verklaringskracht van deze regionale verschillen is veel minder dan men uit de literatuur van wetenschap en beleid in Nederland zou mogen opmaken. Dat er toch nog een significant verband tussen regionale her- 
komst en criminaliteit is gevonden, hangt samen met de grote omvang van de onderzoekspopulatie.

Sociaaleconomische status in Nederland heeft een aanzienlijk grotere verklaringskracht en daarbij is nauwelijks sprake van doorwerking van een regionaal afkomstverschil in Marokko. Het ontbreken van een betaalde werkkring, een laag opleidingsniveau en een laag inkomen voorspellen crimineel gedrag veel beter dan regionale herkomst. Deze uitkomsten pleiten ervoor de oorzaken van de Marokkaanse criminaliteit in Nederland te zoeken en minder in Marokko. Daar komt nog een verschil bij tussen de criminaliteit van de anderhalve en de eerste generatie: kinderen die op jonge leeftijd naar Nederland zijn gekomen, ongeacht hun regionale herkomst, lopen een beduidend grotere kans ooit verdacht te zijn geweest van criminaliteit dan degenen die hun hele jeugd in Marokko hebben doorgebracht.

De conclusie luidt dat de zogenaamde Marokkaanse criminaliteit bij nader inzien een algemeen verschijnsel is in Nederland en niet het gevolg van een plattelandsen Rif-achtergrond van een groot deel van de immigranten. In het licht van de gangbare theorie over de relatie tussen migratie en criminaliteit was deze uitkomst niet opzienbarend. Evenwel: vergeleken met de verwachting die in de literatuur over de regionale achtergronden van de Marokkaanse criminaliteit speciaal in Nederland wordt gewekt, is dit een nogal onverwachte conclusie. Voor een deel zou dit misschien te verklaren zijn uit beperkingen van het materiaal. We beschikken niet over gegevens over interne migratie en criminaliteit die aan de emigratie naar Europa kunnen zijn voorafgegaan. Het is onbekend hoeveel 'stedelijke plattelanders', zoals Van den Berg-Eldering (1978) die noemt, zich onder degenen bevinden die wij hier als afkomstig van het platteland hebben geteld. Dit is wel een belangrijk bezwaar omdat geëmigreerde mannen welbewust hun gezin soms eerst aan de stad in Marokko hebben doen wennen om de culturele overgang niet al te bruusk te maken. Het resultaat zou verder anders hebben kunnen zijn wanneer de samenhang tussen regionale herkomst en criminaliteit op een lager aggregatieniveau zou zijn bestudeerd. De hoge criminaliteit van een streek in zijn geheel kan immers berusten op een criminele traditie van een of enkele plaatsen. Ten slotte moeten we wijzen op het risico van een foutieve causaliteitsredenering bij ons onderzoeksresultaat, waar blijkt dat het hebben van een baan en hogere opleiding het risico op contact met de politie aanzienlijk doet afnemen. Het kan ook zijn dat de criminaliteit onder jongeren zo hoog is dat dit op zichzelf al een reden is om niet meer voor werk of scholing in aanmerking te komen (Bovenkerk, 2014).

Onze conclusie sluit wel goed aan bij onderzoek naar jeugdcriminaliteit waarbij niet is uitgegaan van de veronderstelling dat er een speciaal Marokkaans probleem bestaat dat verklaring behoeft. Er zijn ten eerste theoretische bezwaren geopperd tegen een ongenuanceerd en essentialistisch gebruik van het begrip cultuur als een stabiele en ongedifferentieerde entiteit waar een dwingende kracht van uitgaat die tot delinquentie aanleiding geeft (zie voor een overzicht van bezwaren tegen dit 'culturalisme' Bovenkerk, 2014, 149-154). Dit geldt ipso facto voor de invloed van regionale herkomst. Uit een empirisch onderzoek van De Jong (2007) in Amsterdam-West blijkt dat jongens die een straatcultuur met 
elkaar delen, normen en voorstellingen erop na houden die voor een belangrijk deel door henzelf en in Nederland zijn geconstrueerd. Hun optreden kan volgens De Jong beter worden begrepen als een gevolg van de groepsdynamiek die voortkomt uit het zijn van 'de ander' (allochtoon of Marokkaan). Dat Nederlandse jongens met een Marokkaanse achtergrond overlastgevend en crimineel gedrag als een soort geuzenidentiteit omarmen en dit zelf 'typisch Marokkaans' noemen, wil nog niet zeggen dat daarmee empirisch is vastgesteld dat hun wangedrag direct voortvloeit uit hun etnische afkomst. De Haan (2009, 402-403) wijst erop dat de simplistische culturologische verklaring gemakkelijk leidt tot tautologie.

Dit onderzoek wijst uit dat er bij de veronderstelling over de 'immigrant-crime nexus' ook in dit geval geen reden bestaat om al te veel waarde te hechten aan de mogelijk criminogene achtergrond van de plaats van herkomst van de immigranten. In dit geval hebben we de hypothesen getoetst naar regionale verschillen in één land. Tot nu toe zijn de criminaliteitscijfers van immigranten alleen nog maar vergeleken tussen landen van afkomst en dat levert problemen op van vergelijkbaarheid. Hier is gekeken naar regionale differentiatie binnen een land en daarmee is dat methodologische bezwaar veel minder aanwezig. Vooralsnog sluiten we graag aan bij Solivetti (2010), die op grond van een vergelijking van verschillende immigrantengroepen in verschillende immigratielanden tot de conclusie komt dat de kenmerken van de immigratiesamenlevingen meer over de criminaliteit in etnische groepen verklaren dan de kenmerken van de landen van afkomst.

\section{Literatuur}

Amersfoort, J.M.M. van \& Wusten, H.H. van der (1975). Marokkaanse arbeiders in Nederland. Amsterdam: Sociaal-Geografisch Instituut, Universiteit van Amsterdam.

Amnesty International (2013). Proactief politieoptreden vormt risico voor mensenrechten. Etnisch profileren onderkennen en aanpakken. Rapport Amnesty International, Amsterdam.

Aronowitz, A.A. (2002). Assimilation, acculturation and juvenile delinquency among second generation Turkish youths in Berlin. In: J.D. Freilich, G. Newman, S.G. Shoham \& M. Addad (eds.). Migration, culture conflict and crime. Darmouth: Ashgate, 233-260.

Bahara, H. (2012, 11 oktober). 'Die meisjes vragen erom'. De Groene Amsterdammer.

Bakker, B.F.M. (2009). Micro-integratie. CBS Methodenreeks. Den Haag/Heerlen: Centraal Bureau voor de Statistiek.

Bakker, B.F.M., Rooijen, J. van \& Toor, L. van (2014). The system of social statistical datasets of Statistics Netherlands: an integral approach to the production of registerbased social statistics. Statistical Journal of the International Association for Official Statistics, 30, 411-424.

Beer, J. de, Kuijper, H. \& Noordam, R. (1991). Gezinsvormende, gezinsherenigende en retourmigratie van Turken en Marokkanen. Maandstatistiek van de Bevolking, 39, 38-49.

Berg-Eldering, L. van den (1978). Marokkaanse gezinnen in Nederland. Alphen aan den Rijn: Samsom. 
Blokland, A.A.J., Grimbergen, K., Bernasco, W. \& Nieuwbeerta, P. (2010). Criminaliteit en etniciteit. Criminele carrières van autochtone en allochtone jongeren uit het geboortecohort 1984. Tijdschrift voor Criminologie, 52(2), 122-152.

Boer, S. de (2013). Het volk van Abdelkrim. Actualiteit en geschiedenis van de Marokkaanse Rif. Leeuwarden: Wijdemeer.

Bouhalhoul, R. \& Zwaard, J. van der (1996). Een kwestie van vertrouwen. Gesprekken met Marokkaanse ouders. Rotterdam: uitgave in eigen beheer.

Bouras, N. (2012). Het land van herkomst. Perspectieven op verbondenheid met Marokko, 1960-2010. Hilversum: Verloren.

Bovenkerk, F. (2002). Essay over de oorzaken van allochtone misdaad. In: J. Lucassen \& A. de Ruijter (red.). Nederland multicultureel en pluriform? Een aantal conceptuele studies. Amsterdam: Aksant, 209-245.

Bovenkerk, F. (2014). Marokkaan in Europa, crimineel in Nederland. Een vergelijkende studie. Den Haag: Boom Juridische uitgevers.

Bovenkerk, F., San, M. van, Boone, M., Kort, D. \& Boekhout van Solinge, T. (2009). Loverboys of modern pooierschap. Amsterdam: Pandora, Amstel Uitgevers B.V.

Brons, D., Hilhorst, N. \& Willemsen, F. (2008). Het kennisfundament t.b.v. de aanpak van criminele Marokkaanse jongeren (Cahier 2008-4). Den Haag: Ministerie van Justitie, WODC.

De Mas, P. (1987). L'évolution disparate des marges rurales marocaines: les cas du Rif et du Sous. Plaidoyer pour une recherche scientifique adaptée au monde rural marocain. Bulletin Economique et Social du Maroc, 159-161, 53-62.

De Mas, P. (2001). De poreuze noordkust van Marokko. Migratie, smokkel en hasj. Justitiële verkenningen, 27(5), 87-98.

De Mas, P. \& Haffmans, M.A.F. (1985). De gezinshereniging van Marokkanen in Nederland, 1968-1984: een onderzoek naar de omvang, de aard en de gebieden van herkomst en vestiging. Den Haag: Ministerie van Sociale Zaken en Werkgelegenheid.

Driessen, F.M.H.M., Duursma, F. \& Broekhuizen, J. (2014). De ontwikkeling van de criminaliteit van Rotterdamse autochtone en allochtone jongeren van 12 tot 18 jaar. Amsterdam: Reed Business.

Eisenstadt, S.N. (1954). The absorption of immigrants: a comparative study based mainly on the Jewish community in Palestine and the state of Israel. London: Routledge \& Kegan Paul.

Engbersen, G., Leun, J. van der, Staring, R. \& Kehla, J. (1999). De ongekende stad 2. Inbedding en uitsluiting van illegale vreemdelingen. Amsterdam: Boom.

Ferracuti, F. (1968). European migration and crime. Collected Studies in Criminological Research, 3, 9-76.

Fokkema, T., Harmsen, C. \& Nicolaas, H. (2009). Herkomst en vestiging van de eerste generatie Marokkanen in Nederland. Bevolkingstrends, 3, 51-56.

Gelder, P. van \& Sijtsma, J. (1988). Horse, coke en kansen: sociale risico's en kansen onder Surinaamse en Marokkaanse harddruggebruikers in Amsterdam. Amsterdam: Instituut voor Sociale Geografie.

Gemert, F. van (1998). Ieder voor zich. Kansen, cultuur en criminaliteit van Marokkaanse jongens. Amsterdam: Het Spinhuis.

Gijsberts, M. \& Iedema, J. (2012). Opleidingsniveau van niet-schoolgaanden en leerprestaties in het basisonderwijs. In: M. Gijsberts, W. Huijnk \& J. Dagevos (red.). Jaarrapport integratie 2011. Den Haag: Sociaal en Cultureel Planbureau, 76-126.

Haan, W. de (2009). Met de wijsheid van deze tijd. In: C. Brants \& S. van der Poel (red.). Diverse kwesties. Liber amicorum prof. dr. Frank Bovenkerk. Den Haag: Boom Juridische uitgevers, 393-404. 
Jennissen, R. \& Besjes, G. (2012). Geregistreerde criminaliteit. In: Jaarrapport integratie 2012. Den Haag/Heerlen: Centraal Bureau voor de Statistiek, 173-192.

Jennissen, R. \& Blom, M. (2007). Allochtone en autochtone verdachten van verschillende delicttypen nader bekeken (Cahier 2007-4). Voorburg/Den Haag: Centraal Bureau voor de Statistiek /WODC.

Jong, J.D. de (2007). Kapot moeilijk. Een etnografisch onderzoek naar opvallend delinquent groepsgedrag van 'Marokkaanse' jongens. Amsterdam: Aksant.

Junger, M. (1990). Delinquency and ethnicity. An investigation on social factors relating to delinquency among Moroccan, Turkish, Surinamese and Dutch boys. Deventer/Boston: Kluwer.

Junger, M. (1991). Weerwoord. Tijdschrift voor Criminologie, 33(3), 322-325.

Junger-Tas, J. (2002). Etnische minderheden, maatschappelijke integratie en criminaliteit. In: J. Lucassen \& A. de Ruijter (red.). Nederland multicultureel en pluriform? Een aantal conceptuele studies. Amsterdam: Aksant, 247-277.

Kaufman, P. \& Verbraeck, H. (1986). Marokkaan en verslaafd. Een studie naar randgroepvorming, heroïnegebruik en criminalisering. Utrecht: Rovu.

Laumans, W. \& Schrijver, M. (2014). Mocro maffia. Geld, ambitie en verraad in de onderwereld. Amsterdam: Lebowski Publishers.

Leun, J. van der, Kromhout, M., Easton, M. \& Weerman, F. (2010). Criminaliteit, migratie en etniciteit. Nieuwe richtingen binnen een complex en beladen onderzoeksterrein. Tijdschrift voor Criminologie, 52(2), 107-121.

Leuw, E. (1997). Criminaliteit en etnische minderheden. Een criminologische analyse. Den Haag: WODC.

Malecki, E.J. (2012). Regional social capital: why it matters. Regional Studies, 46(8), 1023-1039.

Mears, D.P. (2001). The immigration-crime nexus: toward an analytic framework for assessing and guiding theory, research, and policy. Sociological Perspectives, 44(1), 1-19.

Noije, L. van \& Kessels, R. (2012). Verdachten, slachtoffers en onveiligheidsgevoelens. In: M. Gijsberts, W. Huijnk \& J. Dagevos (red.). Jaarrapport integratie 2011. Den Haag: Sociaal en Cultureel Planbureau, 203-226.

Park, R.E., Burgess, E.W. \& McKenzie, R.D. (1967). The city. Chicago: University of Chicago Press (oorspronkelijk 1925).

Pels, T. (1998). Opvoeding in Marokkaanse gezinnen in Nederland. Assen: Van Gorcum.

Rumbaut, R.G. (1991). The agony of exile: a study of the migration and adaptation of Indochinese refugee adults and children. In: F.L. Ahearn Jr. \& J.L. Athey (eds.). Refugee children: theory, research, and services. Baltimore: John Hopkins University Press, 53-91.

Rumbaut, R. (2004). Ages, life stages, and generational cohorts: decomposing the immigrant first and second generations in the United States. International Migration Review, 38(3), 1160-1205.

Shadid, W.S. (1979). Moroccan workers in the Netherlands. Leiden: Rijksuniversiteit Leiden.

Shaw, C.R. \& McKay, H.D. (1942). Juvenile delinquency and urban areas: a study of rates of delinquents in relation to differential characteristics of local communities in American cities. Chicago: University of Chicago Press.

Solivetti, L.M. (2010). Immigration, social integration and crime. A cross-national approach. Abingdon: Routledge.

Sutherland, E.H. (1939). Principles of criminology. Chicago: J.B. Lippencott Cy.

Viskil, I. (1999). In een stad waar niemand je kent, kun je doen wat je wilt. Noord-Afrikaanse jongeren in een Amsterdamse coffeeshop. Amsterdam: Het Spinhuis. 
Vugts, P. (2014). Doorgeschoten. De nieuwe generatie onstuitbare criminelen. De Kring (zonder plaats van uitgave).

Werdmölder, H. (1986). Van vriendenkring tot randgroep. Marokkaanse jongeren in een oude stadswijk. Baarn: Het Wereldvenster.

Werdmölder, H. (2005). Marokkaanse lieverdjes. Crimineel en hinderlijk gedrag onder Marokkaanse jongeren. Amsterdam: Balans.

Werdmölder, H. \& Meel, P. (1993). Jeugdige allochtonen en criminaliteit. Een vergelijkend onderzoek onder Marokkaanse, Turkse, Surinaamse en Antilliaanse jongens. Tijdschrift voor Criminologie, 35(3), 252-276.

Wijk, A. van \& Bremmers, B. (2011). Snelle jongens. Een onderzoek naar drugsrunners en daaraan gerelateerd problematiek in Limburg-Zuid. Arnhem: Bureau Beke.

Yaeger, M.G. (1996). Immigrants and criminality: a meta survey. Ottawa: Government of Canada, Ministry of Citizenship and Immigration.

Yarden, I. (2008). Families onder druk. Huiselijk geweld in Marokkaanse en Turkse gezinnen. Amsterdam: Van Gennep. 